\title{
Prospects for Spinel-Stabilized, High-Capacity Lithium-Ion Battery Cathodes
}

Jason R. Croy ${ }^{\mathrm{a}^{*}}$, Joong Sun Park ${ }^{\mathrm{a}}$, Youngho Shin ${ }^{\mathrm{b}}$, Bryan T. Yonemoto ${ }^{\mathrm{a}}$, Mahalingam Balasubramanian ${ }^{\mathrm{c}}$, Brandon R. Long ${ }^{\mathrm{a}, 1}$, Yang Ren ${ }^{\mathrm{c}}$, and Michael M. Thackeray ${ }^{\mathrm{a}}$

${ }^{\mathrm{a}}$ Electrochemical Energy Storage Department, Chemical Sciences and Engineering Division, ${ }^{\mathrm{b}}$ Energy Systems Division, Materials Engineering Research Facility, and ${ }^{C} X$-ray Science Division, Advanced Photon Source, Argonne National Laboratory, Argonne, Illinois 60439, USA

\section{*croy@anl.gov}

Argonne National Laboratory, 9700 South Cass Avenue, Bldg.200, Lemont IL, 60439-4837 Phone: 630-252-5917

Fax: $630-252-4176$

1. Current Address: BASF Corp. 23800 Mercantile Road, Beachwood, OH 44122, USA

\begin{abstract}
Herein we report early results on efforts to optimize the electrochemical performance of a cathode composed of a lithium- and manganese-rich "layered-layered-spinel" (LLS) material for lithium-ion battery applications. Pre-pilot scale synthesis leads to improved particle properties compared with labscale efforts, resulting in high capacities $\left(\sim 200 \mathrm{mAh} \cdot \mathrm{g}^{-1}\right)$ and good energy densities $\left(>700 \mathrm{Wh} \cdot \mathrm{kg}_{\text {oxide }}{ }^{-1}\right)$ in tests with lithium-ion cells. Subsequent surface modifications give further improvements in rate capabilities and high-voltage stability. These results bode well for advances in the performance of this class of lithium- and manganese-rich cathode materials.
\end{abstract}

Keywords: lithium rich, manganese rich, composite, cathode, , lithium-ion

\section{Introduction}

Lithium- and manganese-rich "layered-layered" (LL) cathode materials have been of significant interest for more than a decade due to the substantial capacity gains, improved safety, and lower cost compared with their layered counterparts. Generally denoted, in composite notation, as $\mathrm{xLi}_{2} \mathrm{MnO}_{3} \bullet(1-\mathrm{x}) \mathrm{LiMO}_{2}$ $(\mathrm{M}=\mathrm{Mn}, \mathrm{Ni}$, and $\mathrm{Co})$, this class of electrode materials can deliver high capacities in lithium-ion cells, reaching $250 \mathrm{mAh} \cdot \mathrm{g}^{-1}$ and above [1-4]. However, as is now well-known, these exceedingly high capacities come at the expense of structural stability, where the complex role of oxygen at high states of charge (SOC) leads to oxygen evolution, cation migration, and the irreversible transformation of local structures [5-16]. In particular, transition-metal-layer $\mathrm{Li}$ and $\mathrm{LiMn}_{6}\left(\mathrm{Li}_{2} \mathrm{MnO}_{3}\right.$-type) ordering seems to play a key role in the observed magnitude of these phenomena. These degradation processes ultimately give rise to voltage fade and hysteresis and are likely also related, in part, to the poor rate performance typically observed for LL electrodes. Several reviews have recently been published on the details of voltage fade and hysteresis, as well as the associated structural considerations for this class of materials $[8,10]$.

Voltage fade in layered oxides is characterized by an almost continuous decrease in the average voltage of cells and, consequently, their energy output with cycling [17]. Interestingly, capacity fade is not synonymous with voltage fade in that lithium- and manganese-rich LL materials can deliver anomalously high capacities (>250 $\mathrm{mAh} \cdot \mathrm{g}^{-1}$ ) despite the structural disorder induced by high voltage cycling $[18,19]$. 
This phenomenon may be related to current theories on disordered rock-salt cathodes [6]. While many strategies (e.g., coatings and dopants) have been proposed to reduce significantly this voltage fade, none thus far has been shown to stop or change the actual mechanisms involved with respect to a lithium- and manganese-based system [20,21].Voltage fade is likely an inherent, bulk property of LL materials and is highly correlated to the local structures (including defects) that dictate, to a large extent, lithium site energies $[10,22]$. Following this line of thinking, we inferred that the idea of modifying local domain structures in the pristine materials might provide a viable path to mitigate the structural transformations and voltage fade in these electrodes during cycling. The final goal is to realize low-cost, manganese-rich cathodes capable of delivering high capacities while maintaining good structural stability and energy over long-term cycling. Specifically, while some nickel-rich, layered oxides can already deliver close to $200 \mathrm{mAh} / \mathrm{g}$ at slow rates, a more cost-effective, manganese-rich oxide that can compete with these more expensive options, without detrimental energy fade, is currently unavailable. Therefore, we have initiated a "bottom-up" strategy to achieve such a goal. By starting with lower lithium and manganese loadings, $\mathrm{x}$, in $\mathrm{xLi}_{2} \mathrm{MnO}_{3} \bullet(1-\mathrm{x}) \mathrm{LiMO}_{2}$, and modifying local domains structures to mitigate the mechanisms of energy fade, a platform might be built toward the goal of practical, high-energy, lithium- and manganese-rich cathodes.

Thackeray et al. have been pursuing the strategy of embedding, in small concentration, small domains of a structurally compatible spinel component in the LL systems as a way to introduce stabilizing transition metal (TM) cations into the lithium layers [23, 25]. This strategy offers several advantages: 1 ) the spinel structure contains a 3:1 mix of TMs to Li (and vice versa) in alternate layers, giving it an inherent stability against TM migration; 2 ) the three-dimensional nature of spinel structures allows for fast lithium-ion diffusion; 3 ) the working voltage of spinel-type cathodes can be tuned over a large voltage window, depending on composition [26-30]; 4) unoccupied octahedral sites of the pristine spinel structure can be used to help offset first-cycle irreversible capacity losses inherent to LL materials; and 5) spinel and layered structures are compatible and can be integrated at the nanoscale [31].

These attributes have been exploited to manipulate the local domain structure of LL materials and create complex "layered-layered-spinel" (LLS) electrodes, with promising results [23, 24]. Several challenges associated with LLS electrodes, however, have yet to be overcome: 1) precise control over the final fraction of spinel-type domains incorporated into the final product; 2) control over domain composition; and 3) exacting detail of the actual local structures that ultimately form. With respect to 3 ), previous studies have shown that "spinel" concentrations above $\sim 10-15 \%$ are easily identifiable by typical characterization methods such as X-ray diffraction (XRD), showing expected signatures. However, once the targeted concentration falls below $10 \%$, bulk-averaged techniques are not suitable to accurately characterize changes in the local domain structure, and microscopic analyses like highresolution transmission electron microscopy (TEM) might be the best way to study such samples. In addition, the exact nature of local structures that form may not necessarily have ideal $\mathrm{Li}_{1+\mathrm{x}} \mathrm{M}_{2} \mathrm{O}_{4}$-type, spinel configurations. For example, we have observed signatures resembling $\mathrm{M}_{3} \mathrm{O}_{4}$ spinel components with tetrahedral TMs leading to interesting electrochemical properties. 


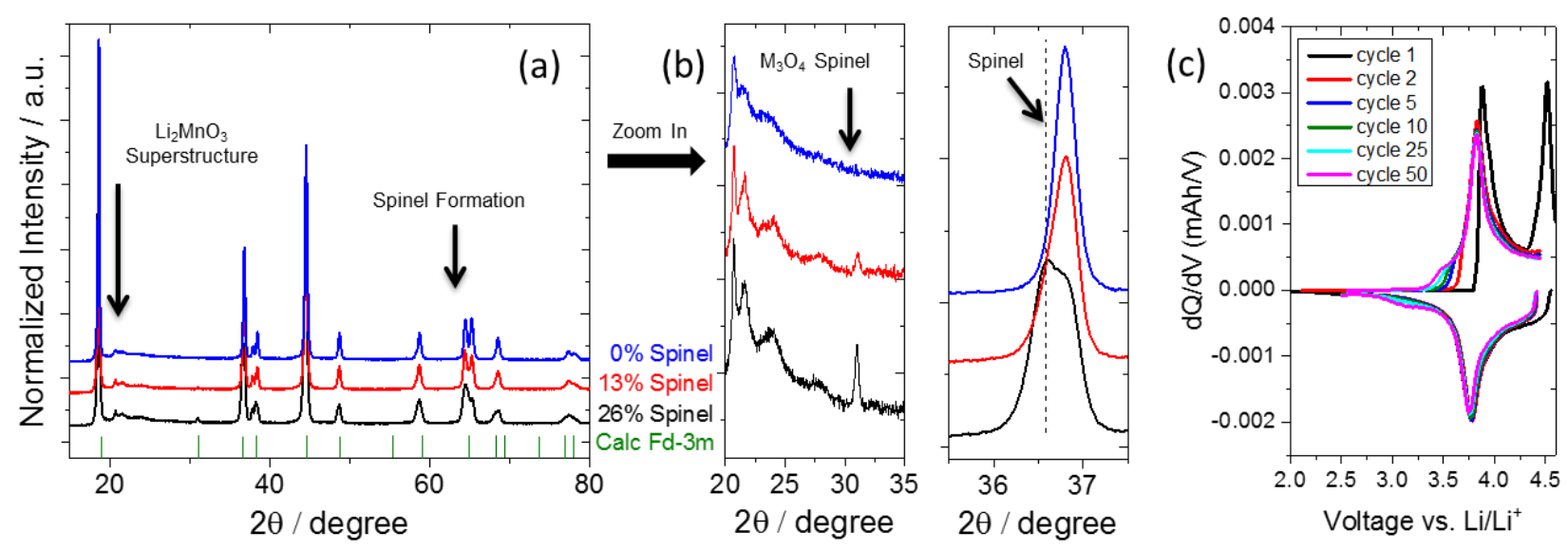

Figure 1 - (a) X-ray diffraction patterns of a $0.25 \mathrm{Li}_{2} \mathrm{MnO}_{3} \bullet 0.75 \mathrm{LiMn}_{0.375} \mathrm{Ni}_{0.375} \mathrm{Co}_{0.25} \mathrm{O}_{2} \mathrm{LL}$ material $(0 \%$ spinel) with targeted spinel contents of $13 \%$ and $26 \%$. Green bars along the bottom show calculated spinel peaks (Fd-3m symmetry). (b) Enlarged view of the $2 \Theta=20-38^{\circ}$ region showing the formation of spinel-type phases. (c) dQ/dV plots of the $13 \%$ spinel LLS electrode during 50 cycles at $4.45-2.5 \mathrm{~V}$ (Li halfcells, $15 \mathrm{~mA} \cdot \mathrm{g}^{-1}$, room temperature).

This result is evident in Figure 1(a), which shows XRD patterns of a series of materials with increasing spinel contents. Clearly visible at $2 \Theta=\sim 32^{\circ}$, using a laboratory X-ray source, is the formation of a new peak as the spinel content increases. The position and intensity are consistent with the (220) plane of a cubic ( $\mathrm{Fd} \overline{3} \mathrm{~m}) \mathrm{M}_{3} \mathrm{O}_{4}$ spinel, in which $\mathrm{M}$ is a transition metal (or metals) together with, or excluding lithium, as shown by the calculated XRD pattern $(a=0.81333 \mathrm{~nm}$ ) in Figure $1(\mathrm{a})$. In addition, the peaks broaden at $2 \Theta=36.5^{\circ}$ (Figure 1 (b)) while the doublet at $\sim 65^{\circ}$ begins to merge as the spinel content increases, indicating the formation of a spinel component. Note that throughout the series, even when the spinel content is $26 \%$, the superstructure peaks from the ordering of $\mathrm{Li}_{2} \mathrm{MnO}_{3}$-like domains $(20=20$ $25^{\circ}$ ) are observed, and that the expected "activation" plateau of the first-cycle charge is clearly visible in Figure 1(c). These electrodes deliver stable capacities of $\sim 180 \mathrm{mAh} \cdot \mathrm{g}^{-1}$. Their excellent structural stability with cycling is highlighted in the $\mathrm{dQ} / \mathrm{dV}$ plots of Figure 1 (c) for an LLS structure with a $13 \%$ spinel content.

Previous studies by Croy et al. aimed at controlling the TM content of lithium layers in LL cathodes have also shown promising results. For example, Figure 2(a) shows in-situ, high-energy, synchrotron X-ray diffraction of a $\mathrm{Li}_{2} \mathrm{MnO}_{3}$ precursor treated in an acidic solution of nickel nitrate, as previously described [32]. The layered $\mathrm{Li}_{2} \mathrm{MnO}_{3}$ structure acts as a template into which nickel cations can be inserted by an ion-exchange-type process. Subsequent annealing drives the nickel into the structure and, depending on the final conditions (e.g., time and temperature of firing), the amount of nickel residing in the lithium layers of the final product can be tuned, as shown by the extended X-ray absorption fine structure (EXAFS) analysis of the coordination number in Figure 2 (b) for a nominal $\mathrm{Li}_{1.2} \mathrm{Mn}_{0.6} \mathrm{Ni}_{0.2} \mathrm{O}_{2}$ cathode material. In addition, rock salt $\mathrm{Li}_{x} \mathrm{Ni}_{1-x} \mathrm{O}$ - and spinel $\mathrm{LiM}_{2} \mathrm{O}_{4}$-type structures can also be formed, dependent on synthesis conditions. These cathodes, despite having complex domain structures, have shown good performance $\left[23,32,33\right.$. Figures $3(\mathrm{a})$-(c) present the performance of the $\mathrm{Li}_{1.2} \mathrm{Mn}_{0.6} \mathrm{Ni}_{0.2} \mathrm{O}_{2}$ electrode material when annealed at $\sim 850^{\circ} \mathrm{C}$, at which the material is not yet fully layered, as shown in Figure 2(a). Figure 3(a) shows the excellent rate capability and capacity retention, while Figures $3(\mathrm{~b})$ and (c) show the good stability of the electrode during cycles 15-25, conducted after the rate test cycles 
shown in Figure 3(a). The ultimate goal of the LLS strategy is, therefore, gaining control over cation occupancies within the lithium layers (octahedral or tetrahedral) to create local configurations that improve electrode cycling stability and performance.

Finally, lithium- and manganese-rich electrodes are known to undergo surface degradation when cycled to high voltages. This degradation can be mitigated by various surface treatments [20, 34, 35]. Therefore, any strategy to mitigate bulk structural changes will need to be coupled with surface protection strategies to maintain surface integrity, good rate performance, and minimal impedance rise with cycling.
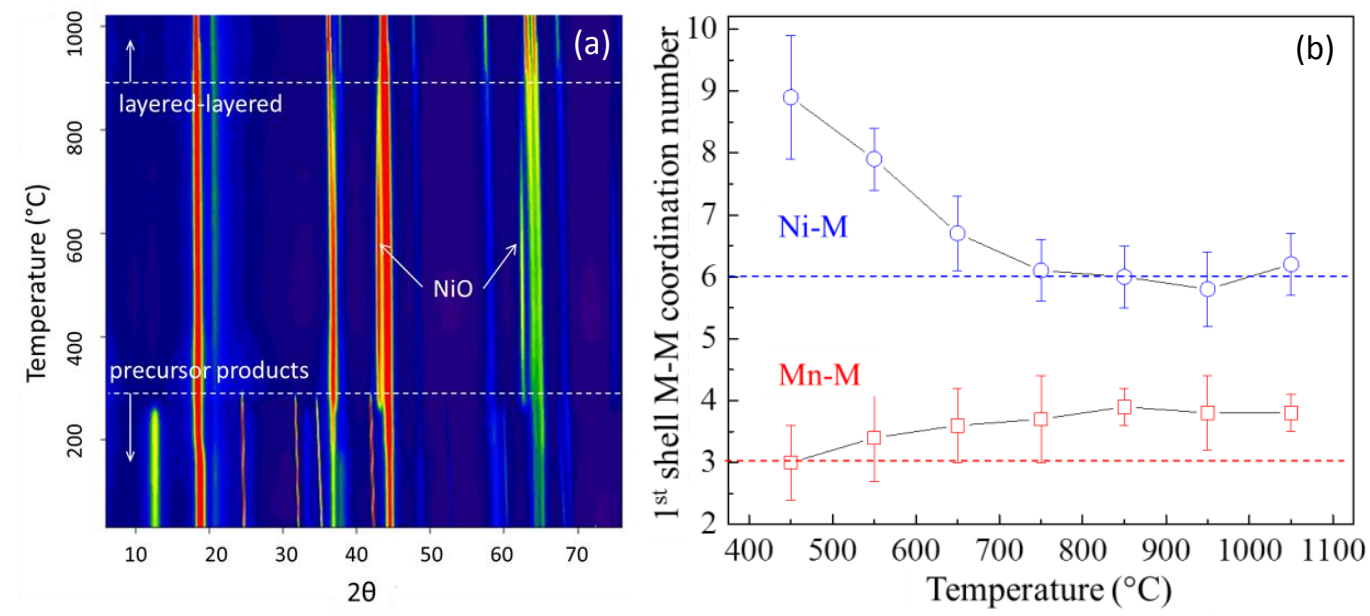

Figure 2 - (a) In-situ, high-energy, synchrotron X-ray diffraction contours during annealing of a $\mathrm{Li}_{2} \mathrm{MnO}_{3}$ precursor template, after treatment in an acidic solution of nickel nitrate to produce $\mathrm{Li}_{1.2} \mathrm{Mn}_{0.6} \mathrm{Ni}_{0.2} \mathrm{O}_{2}$ [32]. (b) EXAFS-derived, second-shell, metal-metal coordination numbers as a function of annealing temperature for similarly synthesized samples.
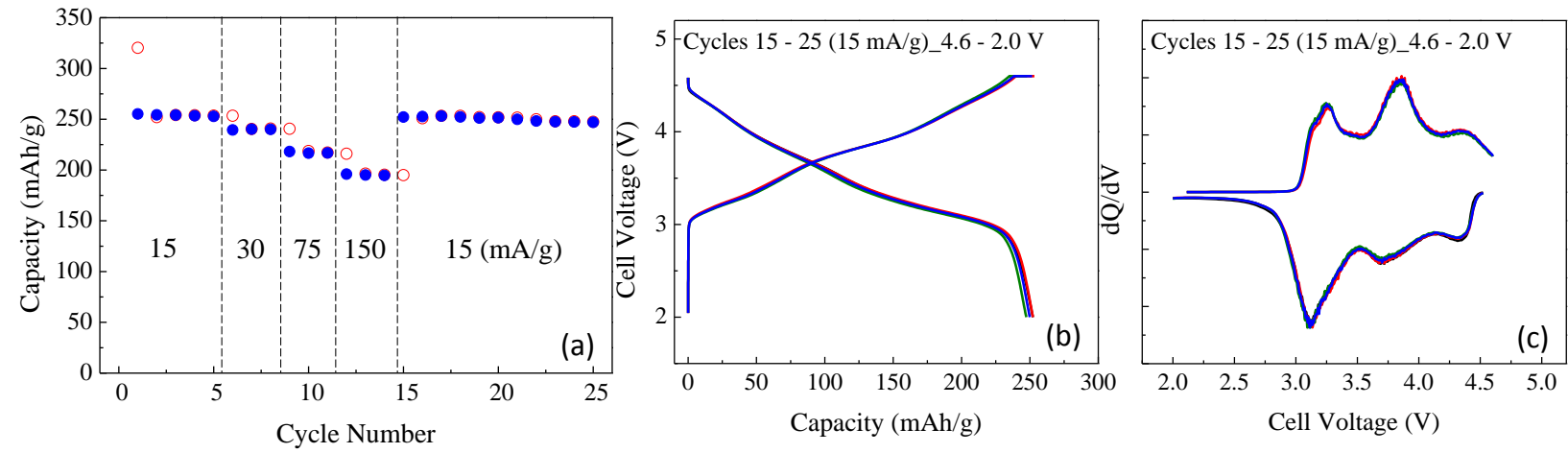

Figure 3 - (a) Rate capability tests for a $\mathrm{Li}_{1.2} \mathrm{Mn}_{0.6} \mathrm{Ni}_{0.2} \mathrm{O}_{2}$ material made via $\mathrm{Li}_{2} \mathrm{MnO}_{3}$ precursors. Charge rates were constant at $15 \mathrm{~mA} \cdot \mathrm{g}^{-1}$ while discharge rates were varied as marked on the figure. (b) Voltage profiles and (c) corresponding dQ/dV plots of cycles $15-25$, conducted after rate testing.

Related to the synthesis of LLS materials, no extensive efforts have thus far been made to produce highquality and robust electrode materials for electrochemical evaluation. While detailed characterization studies are still in progress, we highlight, herein, recent advances in developing lithium- and manganese- 
rich LLS electrodes via pre-pilot scale synthesis and surface treatments of a selected baseline LLS composition.

\section{Experimental}

\subsection{Material Synthesis}

Oxalate co-precipitation: LLS materials were synthesized via several co-precipitation routes. TM oxalate co-precipitation was used for laboratory-scale synthesis because of the excellent reproducibility when these precursors are used. $\mathrm{Mn}_{0.53125} \mathrm{Ni}_{0.28125} \mathrm{Co}_{0.1875} \mathrm{C}_{2} \mathrm{O}_{4} \cdot 2 \mathrm{H}_{2} \mathrm{O}$ precursors were targeted using an aqueous solution (held at $70^{\circ} \mathrm{C}$ ) containing the stoichiometrically required amounts of metal sulfates $\left(\mathrm{MnSO}_{4} \bullet \mathrm{H}_{2} \mathrm{O}, \mathrm{NiSO}_{4} \bullet 6 \mathrm{H}_{2} \mathrm{O}\right.$, added $\mathrm{CoSO}_{4} \bullet 7 \mathrm{H}_{2} \mathrm{O}$ ) added to a solution (also held at $70^{\circ} \mathrm{C}$ ) containing sodium oxalate $\left(\mathrm{Na}_{2} \mathrm{C}_{2} \mathrm{O}_{4}\right)$ and stirred for three hours. The co-precipitated powder was filtered, washed, and dried at $110^{\circ} \mathrm{C}$ overnight followed by thorough mixing with the desired amount of lithium carbonate $\left(\mathrm{Li}_{2} \mathrm{CO}_{3}\right)$ at $850^{\circ} \mathrm{C}$ for 24 hours. The incorporation of spinel into the final product was enabled by careful control of the lithium content (e.g., $\mathrm{Li}_{2} \mathrm{CO}_{3}$ ) in the initial firing process. Specifically, as described in detail in previous reports [23-25, 36], "underlithiation" of an $\mathrm{xLi}_{2} \mathrm{MnO}_{3} \bullet(1-\mathrm{x}) \mathrm{LiMO}_{2} \mathrm{LL}$ composition induces the formation of integrated spinel domains to form a nominal y $\left[x \mathrm{Li}_{2} \mathrm{MnO}_{3} \bullet(1-\mathrm{x}) \mathrm{LiMO}_{2}\right] \bullet(1-\mathrm{y}) \mathrm{Li}_{1+x} \mathrm{M}_{2-\mathrm{x}} \mathrm{O}_{4} \mathrm{LLS}$ composition.

Semi-batch hydroxide co-precipitation: $2 \mathrm{M} \mathrm{Ni}-\mathrm{Mn}-\mathrm{CoSO}_{4}, 1 \mathrm{M} \mathrm{NH}{ }_{4} \mathrm{OH}$, and $4 \mathrm{M} \mathrm{NaOH}$ were pumped separately into a $4 \mathrm{~L}$ stainless-steel stirred tank with a $1.5 \mathrm{~L}$ initial volume. The $\mathrm{pH}$ was kept constant by $\mathrm{NaOH}$ addition via a controller, and the reactor had a $\mathrm{N}_{2}$ head to minimize unwanted oxidation of the precipitated $\mathrm{M}(\mathrm{OH})_{2}$ particles. After 24 hours, the reactor was drained, and the particles washed before drying at $130^{\circ} \mathrm{C}$ under an inert gas (nitrogen). After drying, the precursor hydroxides were mixed with the desired ratio of $\mathrm{LiOH} \cdot \mathrm{H}_{2} \mathrm{O}$ and annealed at $500^{\circ} \mathrm{C}$ for 15 hours, ground, and annealed again at $850^{\circ} \mathrm{C}$ for 15 hours.

Continuous hydroxide and carbonate co-precipitation: Transition metal carbonate precursors were synthesized in a $20 \mathrm{~L}$ continuous stirred tank reactor (CSTR). Aqueous solutions containing the stoichiometrically required metal sulfates $\left(\mathrm{MnSO}_{4} \bullet \mathrm{H}_{2} \mathrm{O}, \mathrm{NiSO}_{4} \bullet 6 \mathrm{H}_{2} \mathrm{O}, \mathrm{CoSO}_{4} \bullet 7 \mathrm{H}_{2} \mathrm{O}\right)$, sodium carbonate $\left(\mathrm{Na}_{2} \mathrm{CO}_{3}\right)$, and ammonium hydroxide $\left(\mathrm{NH}_{4} \mathrm{OH}\right)$ were fed into the CSTR at $50^{\circ} \mathrm{C}$ for over 12 hours. After 12 hours of CSTR operation, the effluent co-precipitated slurry was collected, washed, filtered, and dried at $110^{\circ} \mathrm{C}$ overnight followed by thorough mixing with the desired amounts of lithium carbonate. The final LLS products were produced by annealing at $850^{\circ} \mathrm{C}$ for 24 hours. Co-precipitated hydroxide-based precursors were produced in similar fashion using sodium hydroxide $(\mathrm{NaOH})$ instead of sodium carbonate. The hydroxide precursors were annealed at $820^{\circ} \mathrm{C}$ for 10 hours.

\subsection{Surface Treatments}

The LLS materials were coated by atomic layer deposition (ALD) and wet chemistry routes. For ALD coatings, laminates of LLS electrodes were exposed to sequential pulsing of trimethylaluminum (TMA) and tungsten hexafluoride precursors at $200^{\circ} \mathrm{C}$ to form $\mathrm{AlW}_{\mathrm{x}} \mathrm{F}_{\mathrm{y}}$ surface films. Details of the $\mathrm{AlW}_{\mathrm{x}} \mathrm{F}_{\mathrm{y}}$ materials and ALD processing can be found elsewhere [37]. In addition, 2 wt\% lithium phosphate-based treatments were applied to LLS powders. One gram of powder was immersed overnight in an aqueous solution of lithium nitrate and ammonium phosphate to produce $\mathrm{Li}_{3} \mathrm{PO}_{4}$, with the addition of nickel 
nitrate to yield $\mathrm{Li}_{2.9} \mathrm{Ni}_{0.05} \mathrm{PO}_{4}$. The treated powders were dried and ground and subsequently fired at $500^{\circ} \mathrm{C}$ for eight hours.

\subsection{Materials Characterization}

XRD patterns from $\mathrm{Cu}_{\mathrm{k} \alpha}$ radiation were collected on a Rigaku Miniflex in $\Theta / 2 \Theta$ geometry with a variable slit and on a Bruker D8 ADVANCE with $\mathrm{Cu}$ Ka radiation. The XRD spectra were detected from $2 \Theta=10^{\circ}$ to $80^{\circ}$. The chemical compositions of the samples were measured by inductively coupled plasma-mass spectrometry (ICP-MS, Agilent 7700 Series), and a CILAS 1190 particle size analyzer was used to evaluate particle size and distribution. Scanning electron microscopy (SEM, Hitachi S-4700-II) was used to observe the morphologies of primary and secondary particles in the synthesized materials.

\subsection{Electrochemistry}

Electrode laminates were prepared by coating aluminum foil with $84 \mathrm{wt} \%$ active material, $8 \mathrm{wt} \%$ Super $\mathrm{P}$ carbon, and 8 wt\% polyvinylidene fluoride (PVDF) binder. The electrodes were cycled in Li-half cells with Gen 2 electrolyte [1.2 $\mathrm{M} \mathrm{LiPF}_{6}$ in a 3:7 mixture of ethylene carbonate $(E C)$ and ethyl methyl carbonate (EMC)]. Electrode loadings were maintained at $\sim 5 \mathrm{mg} \cdot \mathrm{cm}^{-2}$ to better assess materials vs. electrode properties. The cells were cycled as described in the text. All tests were done in temperature-controlled ovens held at $30^{\circ} \mathrm{C}$.

\section{Results and Discussion}

Figures $4(\mathrm{a})$ and (b) show capacity and dQ/dV plots, respectively, of a lithium half-cell containing a lithium- and manganese-rich LLS cathode. Capacities of $\sim 185 \mathrm{mAh} \cdot \mathrm{g}^{-1}$ with excellent stability were achieved, as shown in Figure 4(a). Previous studies identified this composition, nominally a $0.25 \mathrm{Li}_{2} \mathrm{MnO}_{3}$ $0.75 \mathrm{LiNi}_{0.375} \mathrm{Mn}_{0.375} \mathrm{Co}_{0.25} \mathrm{O}_{2} \mathrm{LL}$ material with a targeted $15 \%$ "spinel" content, as a promising highcapacity, Mn-rich cathode [23]. As such, we have adopted it as a baseline composition to benchmark future improvements, and the nominal composition is thus referred to as "baseline" herein. Long et al. previously reported detailed characterization of this composition and found small, but identifiable, integrated spinel domains via high-resolution TEM [23]. Although reliable in reproducing elemental compositions of interest, our lab-scale synthesis methods using metal oxalate precursors tend to produce less-than-desirable particles; for example, the particles can be highly porous, as previously reported by Kim et al. [24] To move towards realizing more practical LLS electrodes with higher densities and better morphologies, we have initiated studies on the large-scale synthesis of LLS powders using metal carbonate and hydroxide precursors at the Materials Engineering and Research Facility (MERF) at Argonne National Laboratory. 

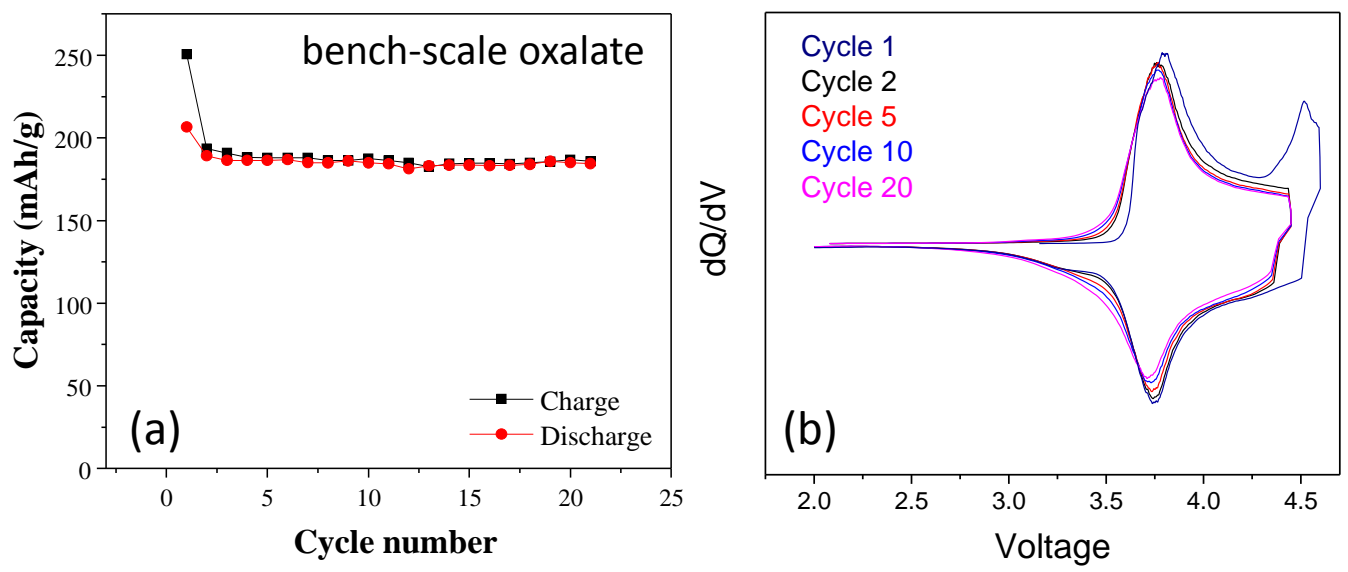

Figure 4 - (a) Capacity vs. cycle number for the baseline LLS composition, and (b) corresponding differential capacity plots. Cycling was done between 4.45 and $2.0 \mathrm{~V}$ after a first-cycle activation between 4.6 and $2.0 \mathrm{~V}$ (Li half-cells, $15 \mathrm{~mA} \cdot \mathrm{g}^{-1}, 30^{\circ} \mathrm{C}$ ).

Figure 5 presents a chart comparing properties of representative LLS particles synthesized by the various methods described in this work (Section 2.1). In general, the carbonate-based precursor particles, produced by the 20 L CSTR, showed the best overall characteristics, including morphology, tap density, and capacity. Ongoing work on the optimization of reactor conditions, for similar compositions, is producing tap densities $>2.00 \mathrm{~g} \cdot \mathrm{cm}^{-3}$ while maintaining high capacities $\left(\sim 200 \mathrm{mAh} \cdot \mathrm{g}^{-1}\right)$. This work will be reported elsewhere and bodes well for high-capacity, Mn-rich compositions.

\begin{tabular}{|c|c|c|c|}
\hline & $\begin{array}{l}\text { CSE LLS } \\
\text { Oxalate }\end{array}$ & $\begin{array}{c}\text { ES20140402 } \\
\text { Scale-up } \\
\text { Carbonate }\end{array}$ & $\begin{array}{c}\text { ES20140710 } \\
\text { Scale-up } \\
\text { Hydroxide }\end{array}$ \\
\hline & Bench scale & $\begin{array}{l}\text { Pre-pilot } \\
\text { Preliminary }\end{array}$ & $\begin{array}{c}\text { Pre-pilot } \\
\text { Preliminary }\end{array}$ \\
\hline $\begin{array}{l}\text { Composition } \\
\text { (by ICP-MS) }\end{array}$ & $\begin{array}{c}\mathrm{Li}_{1.057} \mathrm{Ni}_{0.286} \\
\mathrm{Mn}_{0.519} \mathrm{Co}_{0.195} \mathrm{O}_{\mathrm{y}}\end{array}$ & $\begin{array}{c}\mathrm{Li}_{1.063} \mathrm{Ni}_{0.265} \\
\mathrm{Mn}_{0.542} \mathrm{Co}_{0.193} \mathrm{O}_{\mathrm{y}}\end{array}$ & $\begin{array}{c}\mathrm{Li}_{1.206} \mathrm{Ni}_{0.274} \\
\mathrm{Mn}_{0.534} \mathrm{Co}_{0.191} \mathrm{O}_{\mathrm{y}}\end{array}$ \\
\hline SEM x1,000 & & & \\
\hline SEM x8,000 & & & \\
\hline$D_{10} / D_{50} / D_{90}[\mu \mathrm{m}]$ & $6.3 / 12.3 / 22.3$ & $5.2 / 9.6 / 16.8$ & $2.4 / 4.8 / 8.8$ \\
\hline $\begin{array}{c}\text { Tap density } \\
\text { [g/cc] }\end{array}$ & 1.70 & 1.80 & 1.51 \\
\hline $\begin{array}{c}\text { Initial disch. cap. } \\
@ 10 \mathrm{~mA} / \mathrm{g}\end{array}$ & 193 & 218 & 202 \\
\hline
\end{tabular}

Figure 5 - Chart showing elemental compositions (ICP-MS), SEM images, particle sizes, tap densities, and initial discharge capacities (Li half-cells, 4.6-2.0 V, $10 \mathrm{~mA} \cdot \mathrm{g}^{-1}, 30^{\circ} \mathrm{C}$ ) of representative materials produced by different synthesis routes. 
The XRD patterns for the pre-pilot hydroxide-based LLS compositions (not sown) are in good agreement with the earlier diffraction data for the hydroxide particles of Figure 1; specifically, the formation of spinel-type environments as the Li:TM ratio decreases and the spinel content increases and peak formation at $2 \Theta=\sim 32^{\circ}$ related to tetrahedrally coordinated $A$ ions in an $A[B]_{2} \mathrm{O}_{4}$-type structure. These features are, in general, consistent for metal hydroxides regardless of preparation scale; they depend principally on the lithium content, the Li:TM ratio, the Mn:Ni:Co ratio, and the annealing conditions.

Figure 6 shows the capacity as a function of cycle number and current rate of the electrodes prepared from hydroxide precursors at the MERF facility. Although yielding lower capacities and tap densities than the carbonate-based samples, these powders serve to reiterate a few key aspects of LLS electrodes that have been repeatedly observed $[23,24]$. Namely, as shown in Figures 6 , an optimum spinel content of $10 \%$ or less produces both stable and high capacities, as well as an improved rate performance, relative to a purely layered counterpart. Spinel contents of $5 \%$ and $10 \%$ clearly show the best rate performance as the discharge rate increases, separating themselves from the almost purely layered $2 \%$ composition. This behavior may also be related, in part, to the formation of spinel domains integrated in the surface regions as well as in the bulk. Such configurations were previously reported for the allmanganese system, $\mathrm{Li}_{2-x} \mathrm{MnO}_{y}$ [e.g., $\mathrm{xLi}_{2} \mathrm{MnO}_{3} \bullet(1-\mathrm{x}) \mathrm{LiMn}_{2} \mathrm{O}_{4}$ ], based on high-resolution TEM [31, 38]. Studies on the characterization and optimization of hydroxide-based LLS materials are ongoing.
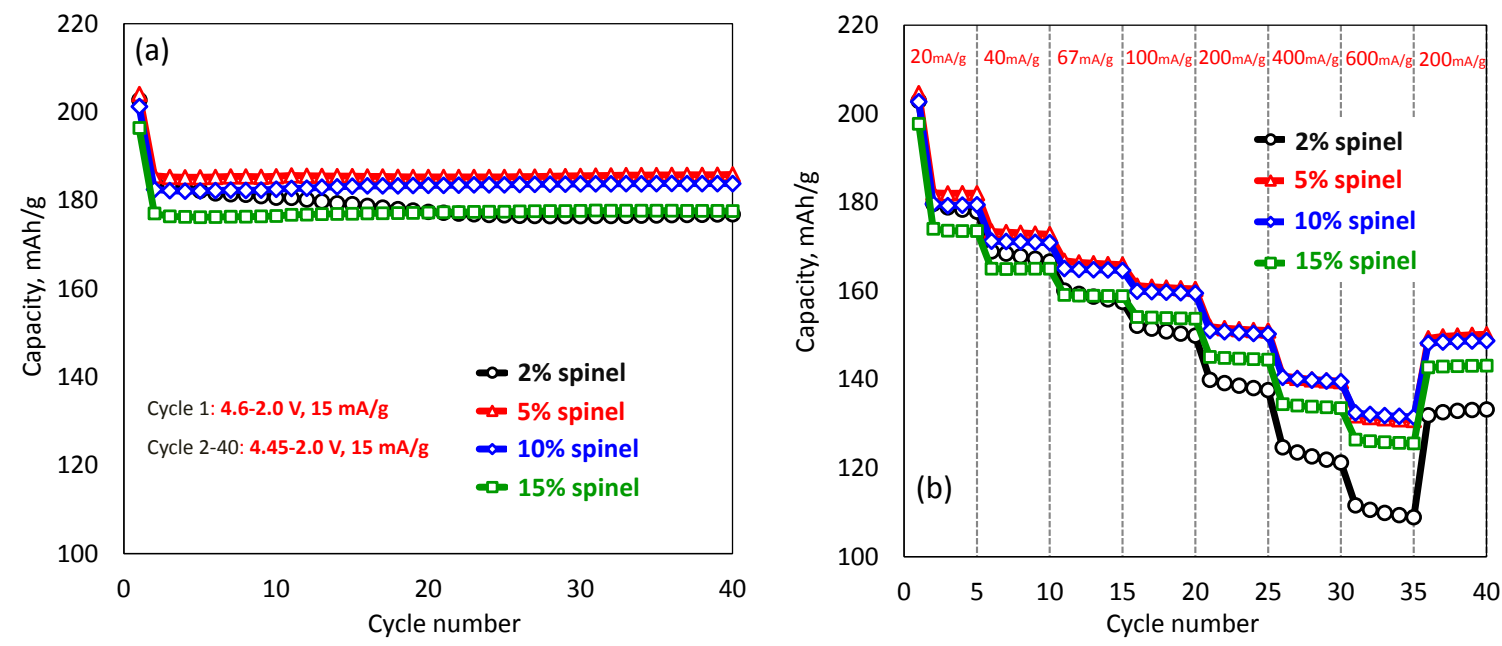

Figure 6 - (a) Capacity vs. cycle number for the baseline, hydroxide-based $0.25 \mathrm{Li}_{2} \mathrm{MnO}_{3}$ $0.75 \mathrm{LiNi}_{0.375} \mathrm{Mn}_{0.375} \mathrm{Co}_{0.25} \mathrm{O}_{2} \mathrm{LL}$ composition with $2-15 \%$ targeted spinel contents. (b) Rate capability of the samples shown in (a). Cycling was performed using Li half-cells at $30^{\circ} \mathrm{C}$. First cycles were done between 4.6 and $2.0 \mathrm{~V}$ at $15 \mathrm{~mA} \cdot \mathrm{g}^{-1}$. Rate cycles were done between 4.45 and $2.5 \mathrm{~V}$ with a constant charge rate of $15 \mathrm{~mA} / \mathrm{g}$ and varied discharge rates as listed.

Figure 7 shows the electrochemical performance of a carbonate-based final product, with the baseline composition, from the MERF facility. These electrodes provided a capacity of $\sim 195 \mathrm{mAh} \cdot \mathrm{g}^{-1}$ when cycled under the same conditions as the oxalate-based and hydroxide-based electrodes (Figures 4 and 6 ). The first-cycle $d Q / d V$ curve clearly shows the typical LL activation plateau; however, the $d Q / d V$ curves of Figure 7 (b) reveal a fairly stable profile on extended cycling to a $4.5-\mathrm{V}$ upper cutoff voltage. 

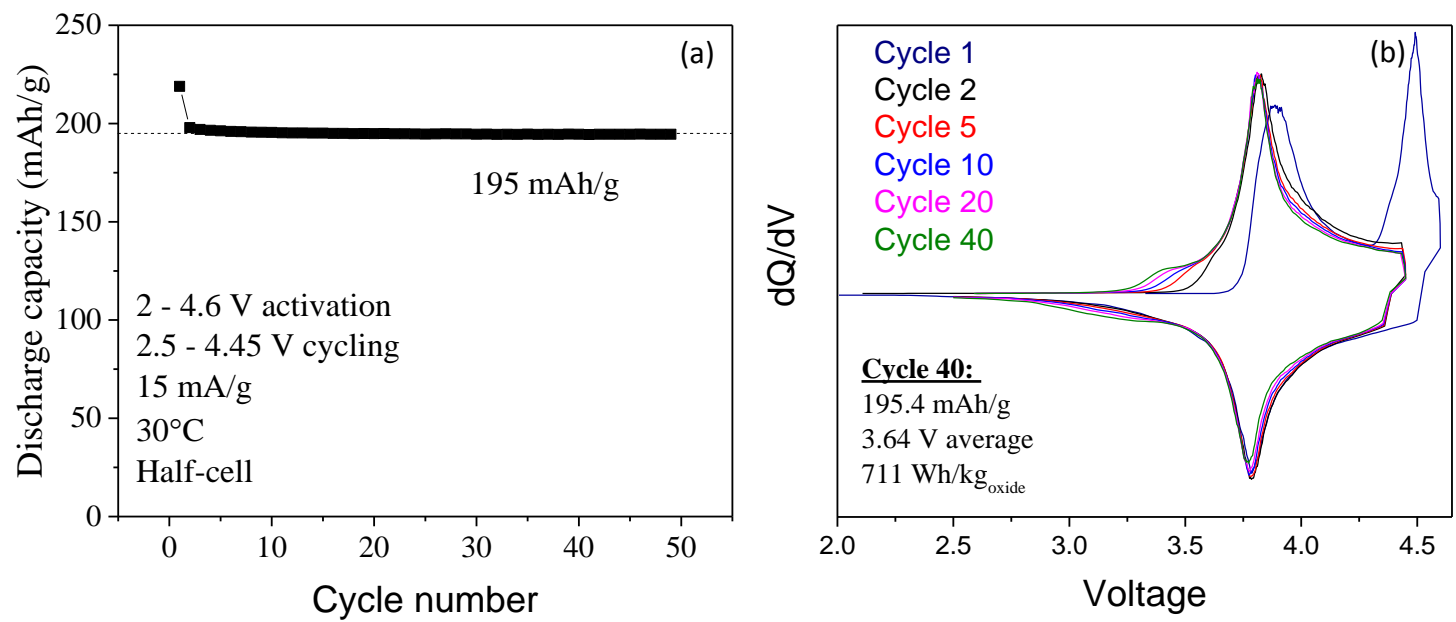

Figure 7 - (a) Capacity vs. cycle number of cells containing the baseline LLS carbonate-based cathode particles synthesized at the MERF facility; and (b) corresponding differential capacity plots. Cells were cycled initially between 4.6 and $2.5 \mathrm{~V}$ (one activation cycle) and thereafter between 4.6 and $2.0 \mathrm{~V}$ (Li half-cells, $15 \mathrm{~mA} \cdot \mathrm{g}^{-1}, 30^{\circ} \mathrm{C}$ ).

As evident in Figure 7, despite indications of some voltage fade, virtually all the cell capacity is delivered above $3.0 \mathrm{~V}$ even after 40 cycles to $\sim 4.5 \mathrm{~V}$. This baseline LLS cathode delivers an average oxide energy density of $711 \mathrm{Wh} \cdot \mathrm{kg}_{\text {oxide }}{ }^{-1}$ under the testing conditions. It is interesting to note that the capacity of the carbonate-based cathode powder is slightly greater (by $\sim 10 \mathrm{mAh} \cdot \mathrm{g}^{-1}$ ) than the hydroxide-based material, which may be due to differences in porosity, exposed crystal facets, and/or surface areas and may account for the lower first-cycle efficiencies of the hydroxide-based cathodes. Although a statistical analysis was not performed, we expect that the morphology and density of the carbonate-based powders (Figure 5) should account for the superior performance of the less dense oxalate-based and hydroxide-based particles -- an indication that optimization of the synthesis process will yield further improvements.

The MERF-produced carbonate-based powders, having the most promising structural and electrochemical properties, were selected for surface protection studies. In this respect, several strategies have already been developed and explored by our group [34, 37, 39, 40]. Building on that work, selected approaches were used to monitor the effects of these surface modifications on the electrochemical performance of our baseline LLS electrode materials.

Figure 8 compares the electrochemical performance of an untreated baseline composition $\left(0.25 \mathrm{Li}_{2} \mathrm{MnO}_{3}\right.$ $0.75 \mathrm{LiNi}_{0.375} \mathrm{Mn}_{0.375} \mathrm{Co}_{0.25} \mathrm{O}_{2}$ with 15\% spinel incorporation) with an electrode laminate that had been coated by ALD with AIW $\mathrm{F}_{y}$, the details of which have been described earlier [37]. In addition, the baseline LLS powders were treated to produce $\mathrm{Li}_{3} \mathrm{PO}_{4}$ - and nickel-substituted $\mathrm{Li}_{2.9} \mathrm{Ni}_{0.05} \mathrm{PO}_{4}$-modified surfaces (i.e., 2 wt\% $\mathrm{Ni}$ ) [34, 40]. Figure 8(a) shows capacity vs. cycle plots for all samples when cycled between 4.6 and $2.5 \mathrm{~V}\left(15 \mathrm{~mA} \cdot \mathrm{g}^{-1}, 30^{\circ} \mathrm{C}\right)$. All samples provided similar capacities, exceeding $200 \mathrm{mAh} \cdot \mathrm{g}^{-1}$. However, of the various surface treatments, the $\mathrm{Li}_{3} \mathrm{PO}_{4}$ - and $\mathrm{Li}_{2.9} \mathrm{Ni}_{0.05} \mathrm{PO}_{4}$-modified powders clearly provided the best rate performance at higher discharge currents, as shown in Figure 8(b), where the two data sets virtually overlap at all rates. Figure 8 (c) shows the $\mathrm{dQ} / \mathrm{dV}$ plots for the untreated and three surface-treated baseline samples for cycle 15. Despite the voltage window being extended from $4.45 \mathrm{~V}$ (Figure 5) to $4.6 \mathrm{~V}$, good cycling stability was achieved with little capacity generation below $3.0 \mathrm{~V}$. 

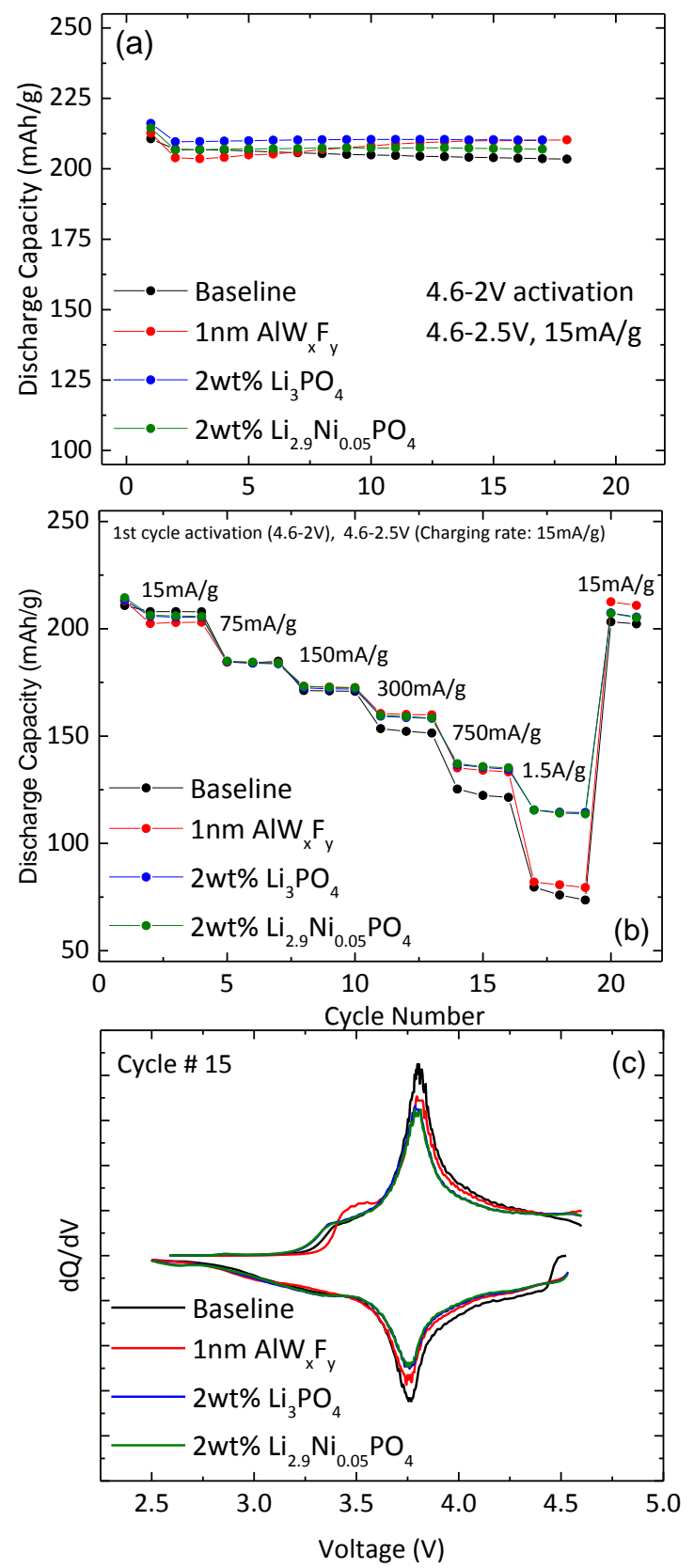

Figure 8 - (a) Capacity vs. cycle plots for surface-modified LLS particles and electrodes as described in the text. All samples were cycled continuously between 4.6 and $2.5 \mathrm{~V}\left(15 \mathrm{~mA} \cdot \mathrm{g}^{-1}, 30^{\circ} \mathrm{C}\right)$. (b) Rate capability of the samples shown in (a) for a constant charge current of $15 \mathrm{~mA} \cdot \mathrm{g}^{-1}$ and various discharge currents as listed. Rate tests were done between 4.6 and $2.5 \mathrm{~V}$ at $30^{\circ} \mathrm{C}$. (c) The $\mathrm{dQ} / \mathrm{dV}$ plot on cycle 15 for baseline and surface-modified LLS materials after continuous cycling between 4.6 and $2.5 \mathrm{~V}$ (Li halfcells, $\left.15 \mathrm{~mA} \cdot \mathrm{g}^{-1}, 30^{\circ} \mathrm{C}\right)$. 


\section{Conclusions}

Pre-pilot scale synthesis has been carried out on a baseline LLS with a composition of $0.25 \mathrm{Li}_{2} \mathrm{MnO}_{3}$ $0.75 \mathrm{LiNi}_{0.375} \mathrm{Mn}_{0.375} \mathrm{Co}_{0.25} \mathrm{O}_{2}$ and a targeted $15 \%$ spinel. The final product produced from carbonate-based precursors showed high capacities $\left(\sim 200 \mathrm{mAh} \cdot \mathrm{g}^{-1}\right)$, good rate performance, and high stability, even when cycled to $4.6 \mathrm{~V}$. Surface treatments on the carbonate-based LLS powders led to further enhancements in rate capability, especially at high discharge rates. The pre-pilot-scale, carbonate-based powders showed some improvement with respect to the laboratory-scale powders, which may be attributed to the higher quality (morphology, porosity, etc.) particles produces by the 20 L CSTR. These early results on the optimization of a baseline LLS composition, via synthesis and surface modifications, are promising and bode well for further improvements to this class of lithium- and manganese-rich electrodes. Ongoing studies have increased tap densities to $\geq 2.00 \mathrm{~g} \cdot \mathrm{cm}^{-3}$, and production of the baseline LLS powders at the kilogram level is in progress to evaluate larger-format pouch cells.

\section{Acknowledgments}

Support from the Advanced Batteries Materials Research (BMR) Program, in particular David Howell and Tien Duong, of the U.S. Department of Energy, Office of Energy Efficiency and Renewable Energy, is gratefully acknowledged. XSD/PNC facilities at the Advanced Photon Source, and research at these facilities, are supported by the U.S. Department of Energy-Basic Energy Sciences, the Canadian Light Source and its funding partners, the University of Washington, and the Advanced Photon Source. The submitted manuscript has been created by UChicago Argonne, LLC, Operator of Argonne National Laboratory ("Argonne"). Argonne, a U.S. Department of Energy Office of Science Laboratory, is operated under Contract No. DE-AC02-06CH11357. The U.S. Government retains for itself, and others acting on its behalf, a paid-up nonexclusive, irrevocable worldwide license in said article to reproduce, prepare derivative works, distribute copies to the public, and perform publicly and display publicly, by or on behalf of the Government.

\section{References}

[1] M.M. Thackeray, C.S. Johnson, J.T. Vaughey, N. Li, S.A. Hackney, Advances in manganese-oxide "composite" electrodes for lithium-ion batteries, J. Mater. Chem. 15 (2005) 2257-2267.

[2] M.M Thackeray, S.-H. Kang, C.S. Johnson, J.T. Vaughey, R. Benedek, S. A. Hackney, $\mathrm{Li}_{2} \mathrm{MnO}_{3}$-stabilized $\mathrm{LiMO}_{2}$ (M= Mn, Ni, Co) electrodes for lithium-ion batteries, J. Mater. Chem. 17 (2007) 3112-3125.

[3] M.M. Thackeray, C. Wolverton, E.D. Isaacs, Electrical energy storage for transportationapproaching the limits of, and going beyond, lithium-ion batteries, Ener. Environ. Sci. 5 (2012) 78547863.

[4] H. Yu, H. Zhou, High-energy cathode materials $\left(\mathrm{Li}_{2} \mathrm{MnO}_{3}-\mathrm{LiMO}_{2}\right)$ for lithium-ion batteries, J. Phys. Chem. Lett. 4 (2013) 1268-1280.

[5] A. R. Armstrong, M. Holzapfel, P. Novák, C.S. Johnson, S.-H. Kang, M.M. Thackeray, P.G. Bruce, Demonstrating oxygen loss and associated structural reorganization in the lithium battery cathode Li $\left[\mathrm{Ni}_{0.2} \mathrm{Li}_{0.2} \mathrm{Mn}_{0.6}\right] \mathrm{O}_{2}$. J. Amer. Chem. Soc. 128 (2006) 8694-8698.

[6] J. Lee, A. Urban, X. Li, D. Su, G. Hautier, G. Ceder, Unlocking the potential of cation-disordered oxides for rechargeable lithium batteries, Science 343 (2014) 519-522.

[7] D.-H. Seo, J. Lee, A. Urban, R. Malik, S. Kang, G. Ceder, The structural and chemical origin of the oxygen redox activity in layered and cation-disordered Li-excess cathode materials. Nature Chem. 8 (2016) 692-697. 
[8] S. Hy, H. Liu, M. Zhang, D. Qian, B.-J. Hwang, Y.S. Meng, Performance and design considerations for lithium excess layered oxide positive electrode materials for lithium ion batteries, Ener. Environ. Sci. 9 (2016) 1931-1954.

[9] K. Luo, M.R. Roberts, R. Hao, N. Guerrini, D.M. Pickup, Y.S. Liu, K. Edström, J. Guo, A.V. Chadwick, L.C. Duda, Charge-compensation in 3d-transition-metal-oxide intercalation cathodes through the generation of localized electron holes on oxygen, Nature Chem. 8 (2016) 684-691.

[10] J.R. Croy, M. Balasubramanian, K.G. Gallagher, A.K. Burrell, Review of the US Department of Energy's "deep dive" effort to understand voltage fade in Li-and Mn-rich cathodes, Acc. Chem. Res. 48 (2015) 2813-2821.

[11] J.R. Croy, H. Iddir, K.G. Gallagher, C.S. Johnson, R. Benedek, M. Balasubramanian, First-charge instabilities of layered-layered lithium-ion-battery materials, Phys. Chem. Chemical Phys. 17 (2015) 24382-24391.

[12] F. Dogan, J.R. Croy, M. Balasubramanian, M.D. Slater, H. Iddir, C.S. Johnson, J.T. Vaughey, B. Key, Solid state NMR studies of $\mathrm{Li}_{2} \mathrm{MnO}_{3}$ and Li-rich cathode materials: Proton insertion, local structure, and voltage fade, J. Electrochem. Soc. 162 (2015) A235-A243.

[13] D. Mohanty, A. Huq, E.A. Payzant, A.S. Sefat, J. Li, D.P. Abraham, D.L. Wood III, C. Daniel, Neutron diffraction and magnetic susceptibility studies on a high-voltage $\mathrm{Li}_{1.2} \mathrm{Mn}_{0.55} \mathrm{Ni}_{0.15} \mathrm{Co}_{0.10} \mathrm{O}_{2}$ lithium ion battery cathode: Insight into the crystal structure, Chem. Mater. 25 (2013) 4064-4070.

[14] D. Mohanty, A.S. Sefat, S. Kalnaus, J. Li, R. A. Meisner, E.A. Payzant, D.P. Abraham, D.L. Wood, Daniel, $C$. Investigating phase transformation in the $\mathrm{Li}_{1.2} \mathrm{CO}_{0.1} \mathrm{Mn}_{0.55} \mathrm{Ni}_{0.15} \mathrm{O}_{2}$ lithium-ion battery cathode during high-voltage hold (4.5 V) via magnetic, X-ray diffraction and electron microscopy studies, J. Mater. Chem. A 1 (2013) 6249-6261.

[15] D. Mohanty, A.S. Sefat, J. Li, R.A. Meisner, A.J. Rondinone, E.A. Payzant, D.P. Abraham, D.L. Wood III, C. Daniel, Correlating cation ordering and voltage fade in a lithium-manganese-rich lithium-ion battery cathode oxide: A joint magnetic susceptibility and TEM study, Phys. Chem. Chemical Phys. 15 (2013) 19496-19509.

[16] D. Mohanty, J. Li, D.P. Abraham, A. Huq, E.A. Payzant, D.L. Wood III, C. Daniel, Unraveling the voltage-fade mechanism in high-energy-density lithium-ion batteries: Origin of the tetrahedral cations for spinel conversion, Chem. Mater. 26 (2014) 6272-6280.

[17] M. Bettge, Y. Li, K. Gallagher, Y. Zhu, Q. Wu, W. Lu, I. Bloom, D.P. Abraham, Voltage fade of layered oxides: Its measurement and impact on energy density. J. Electrochem. Soc. 160 (2013) A2046-A2055. [18] J.R. Croy, D. Kim, M. Balasubramanian, K.G. Gallagher, S.-H. Kang, M.M. Thackeray, Countering the voltage decay in high capacity $\mathrm{xLi}_{2} \mathrm{MnO}_{3} \bullet(1-\mathrm{x}) \mathrm{LiMO}_{2}$ Electrodes $(\mathrm{M}=\mathrm{Mn}, \mathrm{Ni}, \mathrm{Co})$ for $\mathrm{Li}^{+}$-ion batteries, J. Electrochem. Soc. 159 (2012) A781-A790.

[19] T. Ohzuku, M. Nagayama, K. Tsuji, K. Ariyoshi, High-capacity lithium insertion materials of lithium nickel manganese oxides for advanced lithium-ion batteries: Toward rechargeable capacity more than $300 \mathrm{~mA} \mathrm{hg}^{-1}$, J. Mater. Chem. 21 (2011) 10179-10188.

[20] I. Bloom, L. Trahey, A. Abouimrane, I. Belharouak, X. Zhang, Q. Wu, W. Lu, D.P. Abraham, M. Bettge, J. W. Elam, Effect of interface modifications on voltage fade in $0.5 \mathrm{Li}_{2} \mathrm{MnO}_{3} \cdot 0.5 \mathrm{LiNi0} .375 \mathrm{Mn}_{0.375} \mathrm{Co}$ ${ }_{0.25} \mathrm{O}_{2}$ cathode materials, J. Power Sources 249 (2014) 509-514.

[21] E. Lee, R. Koritala, D.J. Miller, C.S. Johnson, Aluminum and gallium substitution into $0.5 \mathrm{Li}_{2} \mathrm{MnO}_{3}$. $0.5 \mathrm{Li}\left(\mathrm{Ni}_{0.375} \mathrm{Mn}_{0.375} \mathrm{Co}_{0.25}\right) \mathrm{O}_{2}$ layered composite and the voltage fade effect, J. Electrochem. Soc. 162 (2015) A322-A329.

[22] F. Dogan, B.R. Long, J.R. Croy, K.G. Gallagher, H. Iddir, J.T. Russell, M. Balasubramanian, B. Key, Reentrant lithium local environments and defect driven electrochemistry of Li-and Mn-rich Li-ion battery cathodes, J. Amer. Chem. Soc. 137 (2015) 2328-2335. 
[23] B.R. Long, J.R. Croy, J.S. Park, J. Wen, D.J. Miller, M.M. Thackeray, Advances in stabilizing 'layeredlayered' $\mathrm{xLi}_{2} \mathrm{MnO}_{3} \cdot(1-\mathrm{x}) \mathrm{LiMO}_{2}(\mathrm{M}=\mathrm{Mn}, \mathrm{Ni}, \mathrm{Co})$ electrodes with a spinel component, J. Electrochem. Soc. 161 (2014) A2160-A2167.

[24] D. Kim, G. Sandi, J.R. Croy, K.G. Gallagher, S.-H. Kang, E. Lee, M.D. Slater, C.S. Johnson, M.M. Thackeray, Composite 'layered-layered-spinel' cathode structures for lithium-ion batteries, J.

Electrochem. Soc. 160 (2013) A31-A38.

[25] S.-H. Park, S.-H. Kang, C. S. Johnson, K. Amine, M.M. Thackeray, Lithium-manganese-nickel-oxide electrodes with integrated layered--spinel structures for lithium batteries, Electrochem. Commun. 9 (2007) 262-268.

[26] M.M. Thackeray, Manganese oxides for lithium batteries, Prog. Solid State Chem. 25 (1997) 1-71.

(27) R. Gummow, M.M. Thackeray, Lithium-cobalt-nickel-oxide cathode materials prepared at $400^{\circ} \mathrm{C}$ for rechargeable lithium batteries, Solid State lonics 53 (1992) 681-687.

[28] R. Gummow, M.M. Thackeray, W. David, S. Hull, Structure and electrochemistry of lithium cobalt oxide synthesised at $400^{\circ} \mathrm{C}$, Mater. Res. Bull. 27 (1992) 327-337.

[29] R. Gummow, D. Liles, Thackeray, M. Spinel versus layered structures for lithium cobalt oxide synthesised at $400^{\circ} \mathrm{C}$, Mater. Res. Bull. 28 (1993) 235-246.

[30] E. Lee, J. Blauwkamp, F.C. Castro, J. Wu, V.P. Dravid, P. Yan, C. Wang, S. Kim, C. Wolverton, R. Benedek, F. Dogan, J. Park, J.R. Croy, M.M. Thackeray, Exploring lithium-cobalt-nickel-oxide spinel electrodes for $\geq 3.5 \mathrm{~V}$ Li-ion cells. Submitted 2016.

[31] C. Johnson, N. Li, J. Vaughey, S. Hackney, M.M. Thackeray, Lithium-manganese oxide electrodes with layered-spinel composite structures $x \mathrm{Li}_{2} \mathrm{MnO}_{3} \cdot(1-\mathrm{x}) \mathrm{Li}_{1+y} \mathrm{Mn}_{2-\mathrm{y}} \mathrm{O}_{4}(0<\mathrm{x}<1,0 \leqslant \mathrm{y} \leqslant 0.33)$ for lithium batteries, Electrochem. Commun. 7 (2005) 528-536.

[32] J.R. Croy, S.-H. Kang, M. Balasubramanian, M.M. Thackeray, $\mathrm{Li}_{2} \mathrm{MnO}_{3}$-based composite cathodes for lithium batteries: A novel synthesis approach and new structures, Electrochem. Commun. 13 (2011) 1063-1066.

[33] J.R. Croy, K.G. Gallagher, M. Balasubramanian, B.R. Long, B. R., M.M. Thackeray, Quantifying hysteresis and voltage fade in $\mathrm{xLi}_{2} \mathrm{MnO}_{3} \bullet(1-\mathrm{x}) \mathrm{LiMn}_{0.5} \mathrm{Ni}_{0.5} \mathrm{O}_{2}$ electrodes as a function of $\mathrm{Li}_{2} \mathrm{MnO}_{3}$ content, J. Electrochem. Soc. 161 (2014) A318-A325.

[34] S.-H. Kang, M.M. Thackeray, Enhancing the rate capability of high capacity $\mathrm{xLi}_{2} \mathrm{MnO}_{3} \bullet(1-\mathrm{x}) \mathrm{LiMO}_{2}$ ( $\mathrm{M}=\mathrm{Mn}, \mathrm{Ni}, \mathrm{Co}$ ) electrodes by $\mathrm{Li}-\mathrm{Ni}-\mathrm{PO}_{4}$, Electrochem. Commun. 11 (2009) 748-751.

[35] X. Zhang, I. Belharouak, L. Li, Y. Lei, J.W. Elam, A. Nie, X. Chen, R.S. Yassar, R.L. Axelbaum, Structural and electrochemical study of $\mathrm{Al}_{2} \mathrm{O}_{3}$ and $\mathrm{TiO}_{2}$ coated $\mathrm{Li}_{1.2} \mathrm{Ni}_{0.13} \mathrm{Mn}_{0.54} \mathrm{Co}_{0.13} \mathrm{O}_{2}$ cathode material using ALD, Adv. Ener. Mater. 3 (2013), 1299-1307.

[36] B. Choi, J. Song, D. Yeon, J.-H. Kim, S. Park, H.E. Kim, J.-H. Park, S. Doo, K. Park, Effect of lithium content on spinel phase evolution in the composite material $\mathrm{Li}_{x} \mathrm{Ni}_{0.25} \mathrm{Co}_{0.10} \mathrm{Mn}_{0.65} \mathrm{O}_{(3.4+x) / 2}(0.8 \leq x \leq 1.6)$ for Li-ion batteries, Solid State Ionics 293 (2016) 77-84.

[37] J.S. Park, A. Mane, J.W. Elam, J.R. Croy, Amorphous metal fluoride passivation coatings prepared by atomic layer deposition on $\mathrm{LiCoO}_{2}$ for Li-ion batteries, Chem. Mater. 27 (2015) 1917-1920.

[38] M.M. Thackeray, J.R. Croy, E. Lee, J.S. Park, User facilities for energy storage research, ES235, DOE Annual Merit Review (2015).

[39] D. Shin, C. Wolverton, J.R. Croy, M. Balasubramanian, S.-H. Kang, C.L. Rivera, M.M. Thackeray, Firstprinciples calculations, electrochemical and x-ray absorption studies of $\mathrm{Li}-\mathrm{Ni}-\mathrm{PO}_{4}$ surface-treated $\mathrm{xLi}_{2} \mathrm{MnO}_{3} \cdot(1-\mathrm{x}) \mathrm{LiMO}_{2}(\mathrm{M}=\mathrm{Mn}, \mathrm{Ni}, \mathrm{Co})$ electrodes for Li-ion batteries, J. Electrochem. Soc. 159 (2011) A121-A127.

[40] J.R. Croy, M. Balasubramanian, D. Kim, S.-H. Kang, M.M. Thackeray, Designing high-capacity, lithium-ion cathodes using x-ray absorption spectroscopy, Chem. Mater. 23 (2011) 5415-5424. 